\title{
Participation and Department of Justice School Desegregation Consent Decrees
}

\author{
Randolph D. Moss
}

The Department of Justice has played a critical role in the movement to desegregate our nation's public schools. ${ }^{1}$ This initiative has taken various forms, from litigation to compliance agreements. In recent years, one technique frequently employed by the Educational Opportunity Section of the Civil Rights Division has been the negotiation of consent decrees. ${ }^{2}$ The use of consent decrees in the context of desegregation raises important concerns about the role of the executive branch in structural reform $^{3}$ or public law litigation. ${ }^{4}$ When a controversy is settled through the use of a

1. For example, the Justice Department brought legal actions against more than five hundred school districts in the first ten years after the enactment of the Civil Rights Act of 1964. See $R$. Ku.ucier, Simpt.s. Justrtie 759 (1977). For a discussion of the activities of the Civil Rights Division under the Kennedy $\Lambda$ dministration and under the Nixon Administration, see, respectively, V. Navasky, Krinnkiny Jusmi:e 96-155 (1977), and Norman, The Strange Career of the Civil Rights Division's Commitment to Brown, 93 YAl.E. L.J. 983, 986-88 (1984)

$\Lambda t$ times the Executive took other historic actions that made school desegregation possible in those areas of the country where state resistance was particularly intense. In 1957, President Eisenhower sent federal troops to Little Rock, Arkansas to ensure the safety of nine children and the enforcement of the court order to desegregate. The history of this federal action is recounted in Cooper v. Aaron, 358 U.S. 1 (1958) (opinion by all nine Justices), and in Little Rock School Dist. v. Pulaski County Special School Dist. No. 1, 584 F. Supp. 328, 331-33 (E.D. Ark.), rev'd on other grounds, 738 F.2d 82 (8th Cir. 1984). In another historic action, President Kennedy sent United States Marshals and members of the Army and Air Force to enforce the Fifth Circuit's order to allow James Meredith to attend the University of Mississippi. See United States v. Barnett, 330 F.2d 369 (5th Cir. 1963) (per curiam). In both of these cases, the Department of Justice played an instrumental role in overcoming vehement resistance to desegregation. See Huston, History of the Office of the Attorney General, in Rol.es of THE: ATtornky General. OF THE United States 1, 22 (1968).

2. Between January 1, 1984 and April 17, 1985, the Civil Rights Division negotiated sixteen school desegregation consent decrees. Hearings on the Department of Justice Authorization Bill Before the Subcomm. on Civil and Constitutional Rights of the House Comm. on the Judiciary, 99th Cong., 1st Sess. (1985) (testimony of William Bradford Reynolds, Assistant Attorney General for Civil Rights). See also L.A. Daily J., Jan. 26, 1984, at 1, col. 2 (Reagan Administration has policy of settling school desegregation suits without trial).

3. See generally Fiss, The Social and Political Foundations of Adjudication, 6 LAw \& HuM. Brinav. 121 (1982); Fiss, The Supreme Court, 1978 Term-Foreword: The Forms of Justice, 93 Hakv. L. Rsv. 1 (1979) [hereinafter cited as Fiss, Forms of Justice]. Professor Fiss uses the phrase "structural reform" to refer to a variant of adjudication where " $a$ judge, confronting a state bureaucracy over values of constitutional dimension, undertakes to restructure the organization to eliminate a threat to those values posed by the present institutional arrangements." Id. at 2.

4. See generally Chayes, The Supreme Court, 1981 Term-Foreword: Public Law Litigation and the Burger Court, 96 Harv. L. Rvv. 4 (1982) (hereinafter cited as Chayes, Public Law Litigation]; Chayes, The Role of the Judge in Public Law Litigation, 89 HARv. L. Rev. 1281 (1976) [hereinafter cited as Chayes, Role of the Judge]. Professor Chayes uses the phrase "public law litigation" to refer to suits in which: "[t]he party structure is sprawling and amorphous ...." "[t]he traditional adversary relationship is suffused and intermixed with negotiating and mediating processes 
consent decree, the legal ideals and procedural protections that govern and legitimate the outcome in fully adjudicated cases are replaced with negotiated compromises. As a result, consent decrees depend on the assent of the parties for authoritative force. Yet, when the executive branch undertakes structural reform litigation, the suit's most direct beneficiaries are not official parties to the suit or the settlement negotiations.

Under current practice, neither the courts nor the Department of Justice provide aggrieved school children and their parents with a right to participate in formulating remedies for the wrongs they have suffered. For example, relying on a "strong presumption" that the Department of Justice will adequately represent the interests of all aggrieved parties, judges repeatedly have denied students and their parents the right to intervene in school desegregation cases brought by the Department of Justice. ${ }^{5}$ This closed process of institutional reform leaves students and their parents with no procedural guarantee that their individual interests will in fact be represented.

Problems inherent in this closed process were demonstrated in the Reagan Administration's first elementary school desegregation suit, initiated against the school board of Bakersfield, California. The Department of Education had found that the schools of Bakersfield were segregated by law. ${ }^{6}$ Minority children were actually bused across town to attend segregated schools. ${ }^{7}$ Pursuant to Title VI of the Civil Rights Act of $1964,{ }^{8}$ the Education Department referred the case to the Department of Justice for action. ${ }^{8}$ On the very day that the Justice Department filed a complaint initiating the suit, it filed a consent decree bringing the suit to an end. United States District Judge Edward Price signed the decree the same day without a hearing. ${ }^{10}$

The Bakersfield decree was an exceptionally weak settlement. ${ }^{11}$ It

... .;" "[t]he judge is the dominant figure in organizing and guiding the case . . . [and] the trial judge has increasingly become the creator and manager of complex forms of ongoing relief, which have widespread effects on persons not before the court and require the judge's continuing involvement in administration and implementation." Id. at 1284.

5. See, e.g., United States v. Louisiana, 90 F.R.D. 358, 363 (E.D. La. 1981), affd, 669 F.2d 314 (5th Cir. 1982); United States v. Board of Educ., 88 F.R.D. 679, 686 (N.D. Ill. 1981); United States v. South Bend Community School Corp., 511 F. Supp. 1352, 1357-59 (N.D. Ind. 1981), affd, 692 F.2d 623 (7th Cir. 1982).

6. See N.Y. Times, Feb. 12, 1984, at A28, col. 1.

7. Id.

8. 42 U.S.C. $\S 2000$ c (1982). See also 34 C.F.R. $§ 100.8(a)(1)(1985)$.

9. Consent Decree, United States v. Bakersfield School Dist., No. CV-F-84-39 (E.D. Cal. Jan. 25, 1984).

10. N.Y. Times, Jan. 26, 1984, at A1, A21, col. 1.

11. Judge Ohanian, the administrative law judge who originally heard the Bakersfield case, called the decree "weak." N.Y. Times, Feb. 12, 1984, at A28, col. 1. Professor Drew S. Days, III (a former Assistant Attorney General for Civil Rights) has argued that the weight of experience suggests that the approach adopted in Bakersfield will probably not achieve "meaningful desegregation." Days, Turning Back the Clock: The Reagan Administration and Civil Rights, 19 Harv. C.R.-C.L. L. 
merely required Bakersfield to establish a series of magnet schools intended to induce voluntary transfers and thus desegregation, ${ }^{12}$ and provided for dismissal of the claim against Bakersfield and termination of court involvement after three years, regardless of whether actual progress was made toward integration of the city's schools. ${ }^{13}$ When the Bakersfield decree is compared with recent settlements achieved in desegregation cases brought by parties other than the federal government, ${ }^{14}$ it becomes clear that the decree embodies a weaker remedy than was legally obtainable ${ }^{15}$

\footnotetext{
REv. 309, 326-27 \& n.80 (1984).
}

In fact, the decree has done little to desegregate the schools of Bakersfield. In a school system with an enrollment in excess of 19,000 students, the plan accounted for only 248 transfers during the first year of its implementation, see First Annual Report of the Bakersfield City School District in United States v. Bakersfield City School Dist., No. CV-F-84-39 (E.D. Cal. Nov. 30, 1984) (report filed pursuant to consent decree), and an additional 249 transfers during the second year, see Second Annual Report of the Bakersfield City School District in United States v. Bakersfield City School Dist., No. CV-F-84-39 (E.D. Cal. Dec. 2, 1985) (report filed pursuant to consent decree). At the end of the second year of the plan's three-year life, one out of every four schools in the district was still not within plus-or-minus $20 \%$ of being racially representative of the Bakersfield public school population-that is, $25 \%$ of the schools had student bodies with either less than $23 \%$ white students or greater than $63 \%$ white students, given a white population of $43 \%$. Id.

12. The plan also included provisions for continuation of a "mini-magnet" program (bringing fourth, fifth and sixth grade students of different races together for one to two hours per day for up to fifteen school days), majority-to-minority tranfers and a program designed to improve reading in the schools that remained segregated. Consent Decree, United States v. Bakersfield City School Dist., No. CV-F-84-39 (E.D. Cal. Jan. 25, 1984).

13. Id.

14. For examples of consent decrees negotiated by private class representatives, see Liddell v. Missouri, 731 F.2d 1294 (8th Cir.) (en banc), cert. denied, 105 S. Ct. 82 (1984); Bronson v. Board of Educ., 604 F. Supp. 68 (S.D. Ohio 1984); San Francisco NAACP v. San Francisco Unified School Dist., 576 F. Supp. 34 (N.D. Cal. 1983). While these settlements do make use of voluntary transfer techniques similar to those employed in the Bakersfield plan, they all differ from the Bakersfield plan in that they set integrative goals mandating that the school districts achieve specific levels of desegregation. See Liddell, 731 F.2d at 1302; Bronson, 604 F. Supp. at 75; San Francisco NAACP, 576 F. Supp. at 53-54. Such mandatory goals are critical to the effectiveness of voluntary plans. See Gewirtz, Choice in the Transition: School Desegregation and the Corrective Ideal, 86 Colum. L. REv. 728, 767-68 (1986); Hawley, Equity and Equality in Education: Characteristics of Effective Desegregated Schools, in EfFrerrive School. Desegreggation 297, 302 (W. Hawley ed. 1981). For a comparison of the Department of Justice settlement in Bakersfield and private class settlements in Liddell, Bronson and San Francisco NAACP, which is critical of the Department's failure to seek mandatory goals, see Hearings on the Department of Justice Authorization Bill Before the Subcomm. on Civil and Constitutional Rights of the House Comm. on the Judiciary, 99th Cong., 1st Sess. (1985) (testimony of William L. Taylor).

15. The reason the Department of Justice accepted such a weak settlement was not because its case was weak. To the contrary, an administrative law judge found in 1978 that the Bakersfield City Schools were intentionally segregated. N.Y. Times, Feb. 12, 1984, at A28, col. 1. Rather, the Justice Department simply announced that " '[m]andatory busing is not acceptable." " L.A. Times, Jan. 26, 1984, at 13, col. 1 (quoting William Bradford Reynolds, Assistant Attorney General for Civil Rights). This conclusion has no basis in law-the Supreme Court has held that busing is generally an appropriate remedy for de jure segregation. See Swann v. Charlotte-Mecklenburg Bd. of Educ., 402 U.S. 1, $30-31$ (1971) ("Desegregation plans cannot be limited to the walk-in school;" thus, busing may be ordered unless "time or distance of travel is so great as to either risk the health of the children or significantly impinge on educational process").

Contrary to the Assistant Attorney General's assertion, case law indicates that it is the Bakersfieldtype plan, and not a busing plan, that fails to meet remedial standards. If the Bakersfield case had 
and than parents and students may have wanted..$^{16}$

Bakersfield in not unique. To the contrary, the Department of Justice has called the Bakersfield decree "the blueprint for desegregation in this Country"17 and has entered similar settlements in a number of other cities. ${ }^{18}$ In none of these cases have all aggrieved individuals had a right to appear before the court. The Department of Justice often does not bring suit against potential defendants until it has already negotiated a settlement with them. The Department files the lawsuit and the consent decree contemporaneously without providing notice to interested persons. ${ }^{18}$ As the House of Representatives Committee on the Judiciary noted, "[t]his secret entry or modification of consent decrees precludes interested persons from acting in the cases."20 Individuals who will be intimately affected by the court-approved settlement are denied the right to make their concerns known to the court. In fact, the Department of Justice in recent years has actually fought to keep parents with views opposed to those of the administration out of the process of negotiating the decree. ${ }^{21}$

In the context of privately initiated school desegregation class actions, the rights and interests of aggrieved students and their parents are pro-

been fully adjudicated to a finding of de jure segregation, precedent and social science evidence indicate that the Department of Justice plan would not have met the standard set forth in Green $v$. County School Bd., 391 U.S. 430, 441 (1968) (requiring plan to be "a sufficient step to "effectuate a transition' to a unitary system"). In particular, the Bakersfield plan is a form of "freedom of choice" plan, and the Court held in Green that "if there are reasonably available other ways, such for illustration as zoning, promising speedier and more effective conversion to a unitary, nonracial school system, 'freedom of choice' must be held unacceptable." Id. (emphasis added). Current scholarship indicates that there are speedier and more effective alternatives to the freedom of choice plan utilized in Bakersfield. See, e.g., J. Hochschild, The New American Dilemma: Liberal Democracy And School. Desegregation 71 (1984) ("Data on magnet schools show that, with a few exceptions, magnets have little effect on racial isolation unless they are part of a districtwide mandatory plan."); Gewirtz, supra note 14, at 755-77 (critiquing defenses of choice remedies). In contrast to the lack of success of Bakersfield-type plans, "[o]ne can point to hundreds of communities," as Professor Days has noted, "that have used busing successfully and stably to desegregate themselves." Days, supra note 11 , at 322 .

16. For example, Mr. Gonzalo Ramirez, President of the local chapter of the Mexican-American Political Association in Bakersfield and a member of the district-created Integration Steering Committee, called the plan "superficial" and said he did not think it would work. N.Y. Times, Feb. 12, 1984, at A28, col. 1. Mr. Ramirez also noted that school officials "controlled" the discussion and that "they came up with what they wanted, a voluntary plan." Id. As a general matter, however, minority support for the Bakersfield plan is a subject of some debate. Contrary to Mr. Ramirez's account, the school district claimed that the minority community supported the settlement. Id. Since there was no hearing in the case, there is no judicial record indicating the degree of minority support for the plan.

17. L.A. Times, Jan. 26, 1984, \& I, at 3, col. 1 (quoting William Bradford Reynolds, Assistant Attorney General for Civil Rights).

18. See, e.g., Consent Decree, United States v. Phoenix Union High School Dist. No. 210, No. 82-302-PHX-CAM (D. Ariz. May 16, 1985) (Phoenix, Ariz.); Consent Order, United States v. Board of Educ., No. C-80-723 (N.D. Ohio Jan. 20, 1984) (Lima, Ohio); Consent Degree, United States v. Texas Educ. Agency, No. CA5-806 (N.D. Tex. Nov. 29, 1983) (Lubbock, Tex.).

19. See House Comm. ON THE Judiciary, Department of Justice Appropriation Authorization Act, Fiscal. Year 1986, H.R. Rep. No. 113, 99th Cong., 1st Sess. 31 (1985).

20. Id.

21. See infra note 90 and accompanying text. 
tected by Rule 23 of the Federal Rules of Civil Procedure. This rule requires as a prerequisite of a class suit a judicial determination that "the claims . . . of the representative parties are typical" of the class and that "the representative parties will fairly and adequately protect the interests of the class."22 Similarly, as a prerequisite to the compromise of a class suit, Rule 23 requires the court to evaluate the settlement and determine that it is fair, reasonable and adequate. ${ }^{23}$ Currently, however, no analogue to Rule 23 exists to be applied to settlements entered between the Department of Justice and local or state school officials. ${ }^{24}$ Where the Department of Justice is the plaintiff, therefore, the process of institutional reform is potentially closed to other interested persons; the multipolar nature of public law litigation is transformed into a bipolar process. Limiting access to the judicial forum in this way undermines the effectiveness and integrity of the process of institutional reform through consent decree.

\section{The NeEd to be HeARd}

\section{A. The Instrumental and Intrinsic Values of Participation}

Few procedural devices are as central to the effective administration of justice as participation. The Supreme Court has recognized the importance of participation and, in some contexts, has held that the opportunity to be heard is "[t]he fundamental requisite of due process."2s One scholar

22. Fy:n. R. Giv. P. 23(a)(3) \& (a)(4). See Georgia State Conference of Branches of NAACP v. Georgia, 99 F.R.D. 16, 28 (S.D. Ga. 1983) (applying Rules 23(a)(3) \& (a)(4)); Vaughns v. Board of Educ., 574 F. Supp. 1280, 1286 (D. Md. 1983) (same).

23. Fro. R. Civ. P. 23(e). See infra notes 99-107 and accompanying text (cases construing Rule 23(e)).

24. William L. Taylor, Director of the Center for National Policy Review, suggested in April of 1985 that Congress enact legislation requiring fairness hearings, like those required under Federal Rule of Civil Procedure 23(c), before a court approves or modifies the settlement of any case brought under the civil rights laws where the United States is a party. Hearings on the Department of Justice Authorization Bill Before the Subcomm. on Civil and Constitutional Rights of the House Comm. on the Judiciary, 99th Cong., 1st Sess. (1985) (testimony of William L. Taylor). In May of 1985, Congress considered a rider to the 1986 Department of Justice Authorization Bill requiring as a condition of funding that the Attorney General provide notice and obtain open hearings before the court prior to entering a consent decree pertaining to civil rights. House COMM. ON THE JUdICIARY, DEPARTMENT OF JUSIIC: APPROPRIATION AUTHORIZATION ACT, FisCAL YEAR 1986, H.R. REP. No. 113, 99th Cong., 1st Sess. 9 (1985). The Authorization Bill was referred out of full committee and included the rider. The Bill, however, never received a "rule" (a technical requirement generally necessary for a bill to come to the House floor) and thus never reached the floor for full consideration.

25. Mullane v. Central Hanover Bank \& Trust Co., 339 U.S. 306, 314 (1950) (quoting Grannis v. Ordean, 234 U.S. 385, 394 (1914)). See also Marshall v. Jerrico, Inc., 446 U.S. 238, 242 (1980) ("requirement of neutrality in adjudicative proceedings safeguards the two central concerns of procedural due process, the prevention of unjustified or mistaken deprivations and the promotion of participation and dialogue by affected individuals in the decisionmaking process"). These cases can be distinguished from Department of Justice consent decrees in that they involve parties who will be formally bound by a judgment rather than effectively bound by a consent decree. See infra notes 52-54 and accompanying text for a discussion of the practical binding effect of Department of Justice consent decrees. 
has gone a step further and argued that participation through proofs and reasoned arguments is the necessary condition of legitimate adjudication. ${ }^{26}$ In the school desegregation context, the Second Circuit has asserted, "[i]t is through the input of interested parties . . . that a just remedy may be devised."27 The values of participation are numerous, but can be classified under two general categories, one "instrumental" and the other "intrinsic." 28

Participation is of instrumental value to the extent that it secures a better result of the adjudication. By helping to ensure that the decision ultimately reached is well-informed, participation increases the likelihood that the outcome will serve the societal and constitutional interests at stake. ${ }^{29}$ In the context of school desegregation litigation, participation provides the decisionmaker with the necessary information concerning the nature of the wrong and of the desired remedy to enable her to reach the optimal constitutional outcome-namely, to ensure that public school systems do not segregate students on the basis of race $^{30}$ and that those that have so segregated take affirmative steps to dismantle the racially dual system "root and branch." 31 In addition, participation by aggrieved individuals increases the likelihood that the result of the decisionmaking process will be based on the judicially cognizable grievance, and not on some extraneous political or personal interest. Finally, participation during the resolution of a school desegregation dispute increases the likelihood that the community will support the plan ultimately adopted, and thereby improves the chances that the court order will be effective.

Participation is of intrinsic value as well. Simply to participate, regard-

26. See generally Fuller, The Forms and Limits of Adjudication, 92 HARv. L. REv. 353 (1978)

[T]he distinguishing characteristic of adjudication lies in the fact that it confers on the affected party a peculiar form of participation in the decision, that of presenting proofs and reasoned arguments for a decision in his favor. Whatever heightens the significance of this participation lifts adjudication toward its optimum expression. Whatever destroys the meaning of that participation destroys the integrity of adjudication itself.

Id. at 364 .

27. United States v. Board of Educ., 605 F.2d 573, 576 (2d Cir. 1979).

28. See L. Tribe, American Constitutional Law § 10-7 (1978) (discussing due process right to be heard).

29. Cf. Id. (participation "ensures that a challenged action accurately reflects the substantive rules applicable to such action"); Eisenberg, Participation, Responsiveness, and the Consultative Process: An Essay for Lon Fuller, 92 HARV. L. REV. 410, 417 (1978) ("Requiring the decisionmaker to attend to the parties' proofs and arguments serves the societal interest of assuring that decisions are well informed.").

30. Today, this proposition of law is so well established as to be beyond reasonable challenge. Its soundness, however, was far from settled at the time of the Court's decision in Brown and shortly thereafter. See, e.g., Wechsler, Toward Neutral Principles of Constitutional Law, 73 Harv. L. REv. 1, 31-35 (1959). Yet for some, the fact that racial segregation is violative of the Fourteenth Amendment was as obvious then as it is now. See Black, The Lawfulness of the Segregation Decisions, 69 YAL.E L.J. 421 (1960).

31. Green v. County School Bd., 391 U.S. 430, 437-38 (1968). 
less of effectiveness, affirms the dignity of the individual. The participating individual is not treated as incapable of useful input or as an object "simply being dealt with." 32 Rather, affected individuals are respected as autonomous beings capable of some control over their destiny. When the potentially excluded groups historically have been oppressed, this concern for ensuring dignity of treatment is all the more acute. Finally, there is the additional benefit that participation is likely to increase the confidence of the public in the fairness of the process. ${ }^{33}$

\section{B. Structural Reform}

The "sprawling"s4 nature of structural reform does not allow, however, for full participation. A particular structural action may affect the interests of all present and future inhabitants of the jurisdiction..$^{35}$ School desegregation litigation provides a clear instance of the expansive nature of public law adjudication. For example, a school suit may involve the interests of future students-including students not yet born-who clearly cannot participate in the judicial determination of the future character of their school district. Public law litigation is also "amorphous;"36 the composition of the group of individuals and interests affected shifts with each possible resolution of the conflict. That is, each possible remedy may have a different set of repercussions which, in turn, affects a different set of individuals. ${ }^{37}$

The fact that it is impossible for all interested individuals to participate meaningfully in public law litigation does not mean, however, that struc-

32. L. TRIBE, supra note 28 , at $\S 10-7$ (emphasis omitted). See also Michelman, Formal and Associational Aims in Procedural Due Process, in Due Process: NOMOS XVIII 126, 127-28 (J.R. Pennock \& J. Chapman eds. 1977) ("[A] participatory opportunity may also be psychologically important to the individual: to have played a part in . . . decisions which are about oneself may be counted important even though the decision, as it turns out, is the most unfavorable one imaginable and one's efforts have not proved influential."); Eisenberg, supra note 29 , at 417 ("Where a decision will have a serious impact on a discrete set of persons, preservation of individual dignity points to the desirability of an ordering process in which those persons will be able to express their view of the matter to the decisionmaker before the decision is made.").

33. Cf. Gellhorn, Public Participation in Administrative Proceedings, 81 YALE L.J. 359, 361 (1972) ("If agency hearings were to become readily available to public participation, confidence in the performance of government institutions and in the fairness of administrative hearings might be measurably enhanced."). On the importance of the opportunity to be heard to the public perception of fairness, see Joint Anti-Fascist Refugee Comm. v. McGrath, 341 U.S. 123, 168-72 (1951) (Frankfurter, J., concurring).

34. Chayes, Role of the Judge, supra note 4, at 1284, 1302.

35. Fiss, Forms of Justice, supra note 3, at 41 (Arkansas prison litigation, for example, involved "inmates, guards, administrators, legislators, taxpayers, indeed all the citizens of the state-present and future," and school litigation is, likewise, polycentric).

36. Chayes, Role of the Judge, supra note 4, at 1284, 1302; Chayes, Public Law Litigation, supra note 4 , at 5 .

37. See Fuller, supra note 26, at 395 ("[T]he various forms that [a remedy] might take ... would have a different set of repercussions and might require in each instance a redefinition of the 'parties affected.' "). 
tural reform suits should not be allowed. The instrumental value of participation can be served by less than full participation. A large crosssection of aggrieved individuals and their representative groups generally can capture and present the various interests at stake. To some extent, less than full participation does diminish the intrinsically valuable effects of participation. At times, however, structural reform may be the only available means of protecting individuals from abuse by relatively powerful institutions such as school systems. ${ }^{38}$ It would be a shallow victory to insist upon full participation in every instance at the price of allowing the rights of individuals to go unvindicated. The intrinsic value of participation can be maximized in the context of structural reform by guaranteeing that those most directly affected, and thus most likely to feel demeaned by exclusion from the decisionmaking process, may participate. Although large and unwieldy, the nature of public law litigation does not require the exclusion of those most directly affected, such as, in school desegregation disputes, minority students and their parents. Indeed, in privately initiated school desegregation class actions the victims do participate as class members with the right to challenge the adequacy of a proposed settlement. ${ }^{39}$ Thus, participation is both possible and desirable in structural reform.

\section{G. Consent Decrees}

When structural reform is achieved through consent decree, participation by those most directly affected is particularly important. In fully adjudicated cases, legal norms, as interpreted and applied by the judge, control the finding of violation and the order of relief. ${ }^{40}$ The presence of the judge, a neutral third party; ${ }^{41}$ the openness of the trial to the public; ${ }^{42}$ the requirement that the judge articulate reasons ${ }^{43}$ for reaching a particular

38. See Fiss, Forms of Justice, supra note 3, at 43-44 (structural reform may be only effective means to empower individuals who have been injured by vast educational system).

39. See, e.g., Bronson v. Board of Educ., 604 F. Supp. 68, 78-81 (S.D. Ohio 1984); San Francisco NAACP v. San Francisco Unified School Dist., 576 F. Supp. 34, 48-51 (N.D. Gal. 1983); Liddell v. Board of Educ., 567 F. Supp. 1037, 1044-45 (E.D. Mo. 1983).

40. In school desegregation cases, the Constitution and court precedent do not define a precise remedy, see infra notes 73-83 and accompanying text; nonetheless, they do establish broad standards such as the requirement of effectiveness, see Green v. County School Bd., 391 U.S. 430 (1968), and the unacceptability of delay, see Griffin v. County School Bd., 377 U.S. 218 (1964).

41. See generally Redish \& Marshall, Adjudicatory Independence and the Values of Procedural Due Process, 95 YAle L.J. 455 (1986) (neutral adjudicator is a necessary, and perhaps sufficient, condition of due process); see also Marshall v. Jerrico, Inc., 446 U.S. 238, 242 (1980); Fiss, Forms of Justice, supra note 3 , at 14 .

42. See Craig v. Harney, 331 U.S. 367, 374 (1947) ("A trial is a public event. What transpires in the court room is public property.").

43. "[B]oth court rules governing adjudicatory procedure and, in some cases, the Constitution's due process clauses require that dispute resolution be accompanied by reasons." Cover, The Uses of Jurisdictional Redundancy: Interest, Ideology, and Innovation, 22 WM. \& MARY L. REV. 639, 643 
decision; and the availability of appeal ${ }^{44}$ help ensure that the judicial process is guided by the rule of law, that our government is one "of laws and not men." In school desegregation cases the relevant remedial rule provides that the school board must "fashion steps which promise realistically to convert promptly to a system without a 'white' school and a 'Negro' school, but just schools." ${ }^{\text {"ts }}$ Because the rule itself is designed primarily to vindicate the constitutional rights of minority school children, adherence to that rule provides some guarantee that the interests of non-party school children will be protected in desegregation suits brought by the Department of Justice.

Legal norms play a less prominent role in the formulation of consent decrees. Consent decrees are generally conceived of as embodying a tension between two modes of law-court order and private contract. ${ }^{46}$ In practice, however, structural reform consent decrees more closely resemble private contracts than court orders. ${ }^{47}$ Consent decrees are the product of

(1981) (footnote omitted). See also Fiss, Forms of Justice, supra note 3, at 13.

44. In the federal system, "[t]he courts of appeals . . . shall have jurisdiction of appeals from all final decisions of the district courts of the United States . . . except where a direct review may be had in the Supreme Court." 28 U.S.C. $\$ 1291$ (1982).

45. Green v. County School Bd., 391 U.S. 430, 442 (1968).

46. For example, one commentator has noted:

[A consent decree] is a kind of legal hermaphrodite, with characteristics both of a contract and a court order. It is contractual in the obvious sense that it is drafted and agreed upon by the parties: it is their bargain, it represents the terms on which they are prepared to settle. But a consent decree is not just a private contract. Unlike a contract, or a private out-of-court settlement, a consent decree can be enforced by citation for contempt of court; it has the authority of a judicial decree.

Schwarzschild, Public Law By Private Bargain: Title VII Consent Decrees and the Fairness of Negotiated Institutional Reform, 1984 DukE L.J. 887, 894-95 (footnotes omitted). See also United States v. ITT Continental Banking Co., 420 U.S. 223, 236 n.10 (1975) ("Consent decrees and orders have attributes both of contracts and judicial decrees").

47. Most consent decrees do not admit violation: some explicitly deny violation, see, e.g., Consent Decree, United States v. Bakersfield City School Dist., No. CV-F-84-39 (E.D. Cal. Jan. 25, 1984); other consent decrees neither admit nor deny violation, see, e.g., United States v. Board of Educ., 88 F.R.D. 679, 681 n.2 (N.D. Ill. 1981); finally, in some cases, a consent decree is entered at the remedial stage after the court has already found a violation, see, e.g., Armstrong v. Board of School Directors, 616 F.2d 305 (7th Cir. 1980). Because no contested issue is before the court, it is not clear that a consent decree presents a "case or controversy" under Article III of the Constitution. But cf. Schwarzschild, supra note 46, at 901-08 (discussing case or controversy requirement in context of employment discrimination consent decrees). When parties "desire precisely the same result," there is no case or controversy. Moore v. Charlotte-Mecklenburg Bd. of Educ., 402 U.S. 47, 47-48 (1971) (per curiam) (both parties arguing anti-busing statute was constitutional). The Supreme Court, however, has rejected the argument that consent decrees do not meet the case or controversy requirement: "The argument ignores the fact that a suit for an injunction deals primarily, not with past violations, but with threatened future ones; and that an injunction may issue to prevent future wrong, although no right has yet been violated." Swift \& Co. v. United States, 276 U.S. 311, 326 (1928). Due to the distinctively historic nature of the wrongful conduct being redressed, it seems peculiar to extend this argument to school desegregation cases.

One significant difference between a consent decree and a contract is that the consent decree is backed by the threat of contempt. However, in the context of structural reform, this difference is largely illusory. Courts historically have been reluctant to impose meaningful contempt sanctions against public officials. See, e.g., United States v. Lynd, 349 F.2d 790 (5th Cir. 1965) (court failed to bring criminal contempt proceeding against Theron Lynd, Registrar of Voters of Forest County, Mis- 
the give-and-take of negotiations rather than the requirement of the rule of law. While legal norms do influence the negotiating process, ${ }^{48}$ in the end the parties accept less, and conversely grant more, than required by the legal ideal..$^{48}$ Furthermore, because consent decrees seldom admit of violation, one might effectively argue that there is no remedial standard or norm that must be met. ${ }^{50}$

Because a consent decree is largely the product of contractual negotiations, the moral force and binding authority of the decree is premised primarily on the parties' consent to be bound. The role of the court is simply to ensure that the compromise reached is not itself "unconstitutional, unlawful, ... . contrary to public policy, or unreasonable."151 The lack of controlling legal norms inherent in the consent decree process becomes troubling when the parties most directly affected by the remedy are not parties to the consent decree and therefore have not agreed to be bound. A government-initiated school desegregation action is not simply a proprie-

sissippi, for failing to comply with court's orders to register black citizens; court's civil contempt order was merely repetition of injunction ordering registration); United States v. Barnett, 346 F.2d 99 (5th Cir. 1965) (court failed to impose sanction on Governor Ross Barnett for civil contempt and refused to find Barnett guilty of criminal contempt even though he repeatedly ignored court's orders to allow James Meredith to attend University of Mississippi); see also O. Fiss \& D. RENDLEMan, INJunCTIONS 441-42 (2d ed. 1984). Courts are particularly reluctant to impose contempt sanctions when the decree violated was a product of consent, especially when enforcement is directed at government officials. See Fiss, Against Settlement, 93 Y ALE L.J. 1073, 1084 (1984).

Absent contempt, the only real difference between a contract and a consent decree is that the consent decree is backed by the prestige and symbolic power of the judiciary. However, as long as courts are unwilling to enforce public law consent decrees with the contempt sanction, their symbolic power is in jeopardy.

48. See generally Mnookin \& Kornhauser, Bargaining in the Shadow of the Law: The Case of Divorce, 88 YALE L.J. 950 (1979); see also Kirp, Legalism and Politics in School Desegregation, 1981 WIS. L. REV. 924, 933.

49. Cf. Alschuler, The Changing Plea Bargaining Debate, 69 CALIF. L. Rev. 652, 703 (1981) ("Adjudication is designed to answer the question of which side is correct on a case-by-case basis. Settlement is not designed to answer this question but to produce an acceptable middle ground.").

50. This position is supported by the predominance of the "linkage principle" in desegregation law. According to this principle, "the scope of the remedy is determined by the nature and extent of the constitutional violation." Milliken v. Bradley, 418 U.S. 717, 744 (1974) (Milliken I). See also Columbus Bd. of Educ. v. Penick, 443 U.S. 449, 465 (1979); Dayton Bd. of Educ. v. Brinkman, 433 U.S. 406, 420 (1977) (Dayton I); Swann v. Charlotte-Mecklenburg Bd. of Educ., 402 U.S. 1, 16 (1971). Thus, absent a finding or admission of violation, school desegregation law requires no remedy. For a criticism of the linkage, or tailoring, principle, see Fiss, Forms of Justice, supra note 3, at 47 ("It suggests that the relationship between remedy and violation is deductive or formal, and thereby gives us an impoverished notion of remedy."). But cf. Gewirtz, supra note 14, at 733 (the linkage principle "is actually a powerful engine of transformation").

A formalistic application of the linkage principle to consent decrees ignores that the denial of violation is often merely pro forma; almost all consent decrecs take the form: "'We didn't do it. We agree not to do it again." " Britton v. South Bend Community School Corp., 775 F.2d 794, 801 n.10 (7th Cir. 1985), vacated, reh'g en banc granted, 783 F.2d 105 (7th Cir. 1986). Nonetheless, the absence of a factual record of violation or an agreement over the extent of the violation does make it difficult to determine the scope of the remedy required by desegregation law.

51. United States v. South Bend Community School Corp., 692 F.2d 623, 628 (7th Cir. 1982) (quoting United States v. City of Miami, 614 F.2d 1322, 1333 (5th Cir. 1980), affd in relevant part en banc, 664 F.2d 435 (1981)). 
tary dispute between the Justice Department and the local school board. Rather, the direct injury being redressed is one inflicted upon non-parties to the decree. It is the minority students who will be most affected by the nature of the remedy which is provided for the injury they have suffered.

In practice, the consent decree also makes independent assertions of legal rights by the victims of segregation significantly more difficult. Intervention is rarely available to private plaintiffs in school desegregation suits brought by the Justice Department. ${ }^{\mathbf{5 2}}$ In addition, courts are generally not receptive to a second suit concerning the same structural wrong. ${ }^{53}$ Finally, a consent decree will not be modified unless the moving party demonstrates changed conditions evoking a "hardship so extreme and unexpected" as to make the decree oppressive. ${ }^{.4}$ Participation would afford these individuals an opportunity to look out for their interests in the absence of controlling legal norms and extensive judicial involvement.

52. Due to a strong presumption that the United States will adequately represent aggrieved students in government-initiated school desegregation actions, the district courts rarely permit either intervention as of right or permissive intervention in these suits. See United States v. Louisiana, 90 F.R.D. 358 (E.D. La. 1981), affd, 669 F.2d 314 (5th Cir. 1982) (motion to intervene denied on ground that United States is adequate representative); United States v. Board of Educ., 88 F.R.D. 679 (N.D. Ill. 1981) (same); United States v. South Bend Community School Corp., 511 F. Supp. 1352 (N.D. Ind. 1981), affd, 692 F.2d 623 (7th Cir 1982) (same). To rebut this presumption, the proposed intervenors must make a "very compelling showing" that Department of Justice representation is inadequate. United States v. Board of Educ., 88 F.R.D. at 686; South Bend Community School Corp., 511 F. Supp. at 1357. For example, the proposed intervenors must show collusion between the Department of Justice and the defendant or that the Department is acting in bad faith or with gross negligence. Such a showing is extremely difficult to make. See United States v. South Bend Community School Corp., 692 F.2d 623, 628 (7th Cir. 1982); United States v. Louisiana, 90 F.R.D. at 364. When the Department is negotiating a consent decree, the court is even less likely to permit intervention because doing so may frustrate the settlement process and settlement is encouraged by the federal courts. See United States v. Board of Educ., 88 F.R.D. at 682.

53. Although the suit is not formally res judicata, a court may nonetheless feel constrained by a prior consent decree. See Zimmer \& Sullivan, Consent Decree Settlments by Administrative Agencies in Antitrust and Employment Discrimination: Optimizing Public and Private Interests, 1976 DuKE L.J. 163, 196-200 \& n.110. A court may be reluctant to issue a second injunction because multiple structural injunctions are likely to conflict, placing the defendant in the "untenable position of having to disobey one of the issuing courts." Note, Intervention in Government Enforcement Actions, 89 Harv. L. Rev. 1174, 1183 (1976). See also United States v. City of Jackson, 519 F.2d 1147, 1152 n.10 (5th Cir. 1975) ("In fashioning injunctive relief, of course, courts should and do take care to avoid overlapping or conflicting injunctive commands."); Leisner v. New York Telephone Co., 358 F. Supp. 359, 369-70 (S.D. N.Y. 1973) ("[T]his court will avoid granting relief which is merely duplicative of, or which conflicts with, relief granted in the consent decree."). Principles of comity may also restrict subsequent injunctive relief. The Supreme Court, in Sam Fox Publishing Co. v. United States, wrote in dictum:

[A]ppellants argue that even should they not be legally precluded from bringing a private action, nevertheless the very existence of the outstanding decree would as a matter of comity either preclude further relief or operate to limit the relief some future equity court might decree. . . . [T] $]$ here is considerable weight to the argument that the court will feel constrained as a matter of comity at least to build on the foundations of the present decree.

366 U.S. 683, 694 (1961) (antitrust consent decree).

54. United States v. Swift \& Co., 286 U.S. 106, 119 (1932). See also EEOC v. Safeway Stores, Inc., 611 F.2d 795 (10th Cir. 1979) (employment discrimination). But $c f$. Note, The Modification of Consent Decrees in Institutional Reform Litigation, 99 HARV. L. REv. 1020 (1986) (arguing that Supreme Court should adopt flexible standard for modifying institutional reform consent decrees). 


\section{The Roles of Justice}

To all of this one might reply that representation is an adequate form of participation (in fact, the predominant form of participation in our judicial system) and that the Department of Justice adequately represents all legitimately interested individuals in government-initiated school desegregation actions. Gareful consideration of the roles of the Department of Justice and its director, the Attorney General, however, reveals that the Department does not, and cannot, represent all interested individuals.

Almost one-hundred years ago the Supreme Court wrote, "[t]here is no very specific statement of the general duties of the Attorney General." Beyond the rather vague duty to "[r]epresent the United States in legal matters generally," "so the role of the Attorney General to this day remains ambiguous. One reason for this continuing difficulty in defining the precise role of the Attorney General is that she does not perform simply one role, but acts in multiple capacities.

\section{A. The Executive as Master}

First, the Attorney General represents the interests of the Executive. ${ }^{87}$ The President appoints the Attorney General with the advice and consent of the Senate, ${ }^{58}$ and, likewise, may fire her. ${ }^{59}$ Furthermore, the Attorney General is a member of the President's cabinet ${ }^{80}$ and thus has a "close and continuing relationship with the President." the Attorney General's role becomes "deeply and inextricably interwoven with the policy decisions and directions of the President and his administration."

55. United States v. San Jacinto Tin Co., 125 U.S. 273, 278 (1888).

56. 28 C.F.R. $\S 0.5$ (b) (1985). See also Huston, supra note 1 , at 1 . The current regulations do not differ signicantly from the language of Section 35 of the first Judiciary Act, which created the Office of the Attorney General:

And there shall also be appointed a meet person, learned in the law, to act as attorney-general

for the United States ... whose duty it shall be to prosecute and conduct all suits in the

Supreme Court in which the United States shall be concerned, and to give his advice and opinion upon questions of law when required by the President of the United States, or when requested by the heads of any departments, touching any matters that may concern their departments....

Judiciary Act of 1789 , ch. 20, § 35, 1 Stat. 92, 93.

57. See Miller, The Attorney General as the President's Lawyer, in Roles OF THE ATtORNEY General of THe United States 41, 47 (1968) (Attorney General is a "lawyer and the President is his most important client").

58. 28 U.S.C. $\S 503$ (1982).

59. Marshall, The Control of the Public Lawyer, in LAw AND THE AMERICAN FUTURE 167, 173 (M. Schwartz ed. 1976).

60. The Untred States Government Manual 1985 866 , Office of the Federal Register, NAtional ARchives and ReCords Administration 77 (1985).

61. See Miller, supra note 57 , at 41 .

62. Marshall, supra note 59 , at 177.

It is not correct, for example, to conceive of the enforcement of the civil rights laws as a piece 
To the extent that the Attorney General acts as the Executive's attorney in bringing a school desegregation suit, the victims of school segregation are represented only insofar as Executive policy coincides with their interests. Given the broader concerns of the Executive, however, divergence is likely. The reargument on remedy in Brown v. Board of Education ${ }^{63}$ provides an example of this divergence. The NAACP, arguing on behalf of the plaintiffs, strongly opposed the "all deliberate speed" formula:

Where a substantial constitutional right would be impaired by delay, this Court has refused to postpone injunctive relief even in the face of the gravest of public considerations suggested as justifications therefor. ${ }^{84}$

The Department of Justice, arguing as an amicus, expressed a different position:

The question is always one of determining how, in the light of the facts presented and within the limits of the power possessed by it, the Court can best insure the removal of the condition of illegality in a manner comporting not only with the interests of the parties but also, to the extent it may be involved, with the public interest. ${ }^{65}$

The reason the arguments differ is apparent: The Department of Justice represented the Executive and the NAAGP represented the plaintiffs in Brown. Hence, in its role as the representative of the Executive, the Department of Justice does not act as a representative of the victims of segregation, and thus, there is no participation through representation.

\section{B. Congress as Master}

The role of the Attorney General, however, is more complex than simply acting as legal counsel for the Executive. While the President maintains the power to appoint and dismiss the Attorney General, Congress holds the power of confirmation, ${ }^{\text {Bs }}$ controls the appropriations pro-

\footnotetext{
of neutral law enforcement work that should be handled by technically skilled trial lawyers without policy and political emphasis. The position of the Department of Justice on such matters as busing, school district consolidation, and affirmative action plans does not flow from neutral principles, nor can it or should it be insulated by institutional organization from the principal positions developed in HEW, Labor, or other cabinet-rank departments accountable to the President.
} Id.

63. 349 U.S. 294 (1955) (Brown II).

64. Brief for the Appellants in Nos. 1, 2 and 3 and for Respondents in No. 5 on Further Reargument at 11, Brown v. Board of Educ., 349 U.S. 294 (1955) (Brown II) (emphasis added).

65. Brief for the United States on the Further Argument of the Question of Relief at 4, Brown v. Board of Educ., 349 U.S. 294 (1955) (Brown II) (emphasis added).

66. U.S. ConST. art. II, § 2, cl. 2; 28 U.S.C. $\S 503$ (1982). 
cess, ${ }^{87}$ and, most important, is the source of standing for the Department of Justice to bring civil suits such as school desegregation actions. ${ }^{68}$ When Congress authorizes the Department to bring civil actions, it concurrently defines particular roles for the Attorney General. As a result, the role is a product of the specific legislation. The Justice Department's standing to bring school desegregation suits is premised on Titles $\mathrm{IV}^{60}$ and $\mathrm{VI}^{70}$ of the Civil Rights Act of 1964.

Two possible representational roles for the Attorney General can be discerned from the language and history of Titles IV and VI. First, Congress authorized the Attorney General to bring school desegregation cases to protect the national interest in a system free from invidious discrimination violative of the Fifth and Fourteenth Amendments. ${ }^{71}$ Second, Con-

67. See McGrain v. Daugherty, 273 U.S. 135, 178 (1927) ("the [Justice] department is maintained and its activities are carried on under such appropriations as in the judgment of Congress are needed from year to year").

68. The issue of nonstatutory standing has been the subject of some debate. See Note, Protecting the Public Interest: Nonstatutory Suits by the United States, 89 YALE L.J. 118 (1979); Note, Nonstatutory Executive Authority to Bring Suit, 85 HARv. L. REv. 1566 (1972). The Supreme Court on occasion has held that the Department of Justice has nonstatutory standing to sue in the public interest. See In re Debs, 158 U.S. 564 (1895); see also United States v. Brand Jewelers, Inc., 318 F. Supp. 1293 (S.D.N.Y. 1970). The Supreme Court has never rejected or accepted nonstatutory standing in school desegregation cases. In 1963, however, the Civil Rights Division unsuccessfully asserted nonstatutory standing in several school desegregation suits before federal district courts. See 1963 ATT'Y GEN. ANN. REP. 187 (listing six suits, five unsuccessful). Enactment of the Civil Rights Act of 1964, which provided statutory standing to the Department, made it unnecessary to seek Supreme Court review. Hence, school desegregation suits by the Department today are uniformly premised on this statutory standing.

69. 42 U.S.C. $\S 2000 c$ (1982). Title IV authorizes the Secretary of Education to provide technical assistance to aid public schools in desegregating and authorizes the Attorney General to institute civil actions against public schools systems that segregate.

70. 42 U.S.C. $\$ 2000$ d (1982). Title VI prohibits racial and ethnic discrimination in programs or activities receiving federal financial assistance.

71. Senator Hubert Humphrey, the recognized spokesperson for the Johnson Administration, see G. ORfield, The Reconstruction of Southern Education 40 (1969), stated in debate that the purpose of Title IV was to pursue the public interest in fundamental political, moral and constitutional principles. Referring to Titles III and IV, Senator Humphrey said: "It is difficult to imagine a case which more clearly justifies an authorization to the United States to sue in the public interest." 110 Cong. Rec. 6542 (1964). Senator Paul Douglas expressed a similar understanding of Title IV. He argued:

Is school desegregation, then, a question which it is appropriate for the Attorney General to litigate? Of course it is. [T] he interest at stake is a national interest, on several levels. It is of the highest importance for the integrity of our system of government that the commands of the Constitution be obeyed, and that the rights assured by that charter be vindicated.

Statutory History of the Unired States: 2 Givil Rights 1278-79 (B. Schwartz ed. 1970). Title VI embodies a similar objective. As Senator Humphrey stated during debate:

The purpose of title VI is to make sure that funds of the United States are not used to support racial discrimination. In many instances the practices of segregation or discrimination, which title VI seeks to end, are unconstitutional. This is clearly so wherever Federal funds go to a State agency [such as a school board] which engages in racial discrimination. . . In all cases, such discrimination is contrary to national policy, and to the moral sense of the Nation. Thus, title VI is simply designed to insure that Federal funds are spent in accordance with the Constitution and the moral sense of the Nation.

110 Cong. ReC. 6544 (1964). 
gress wanted to provide a means of facilitating the protection of an individual's right to attend a unitary school system where the burden of selfprotection is high. ${ }^{72}$ In both roles, Department of Justice representation does not diminish the need for participation.

\section{Pursuing the National Interest in a Constitutional School System}

One might contend that the Department of Justice, in pursuing the national interest in a constitutional school system, effectively represents all those who have a stake in seeing the desegregation opinions enforced. Under this view, the national interest in enforcing the Constitution subsumes the interests of individual victims of segregation in seeking remedies

72. Title IV may be viewed as authorizing the Attorney General to act not on behalf of the general public, but more exclusively on behalf of the victims of school segregation. The House Committee on the Judiciary wrote: "The committee . . . has adopted a provision authorizing the Attorney General . . . to institute a legal action in behalf of school children . . . . H.R. REP. No. 914, part 2, 88th Cong., 1st Sess. 22 (1963). Title IV requires the Attorney General to certify that a parent has filed a meritorious complaint with the Department of Justice and that the parent is unable "to initiate and maintain appropriate legal proceedings for relief." 42 U.S.C. $\S 2000$ c-6 (1982). A parent's inability to bear the expense of a protracted action against state authorities satisfies this requirement. See id. This provision can be understood as a means of restricting Department of Justice authorization to sue to those cases where no suit would otherwise be brought. See 110 CoNG. REC. 6542 (1964) (statement of Sen. Humphrey). Alternatively, however, the provision can be understood as postively authorizing the Attorney General to protect the constitutional interest in attending a unitary school system of minority students who are unable to bring suit themselves. Senator Jacob Javits argued that the Civil Rights Act of 1964 was much like Part III of the Civil Rights Act of 1957 as first introduced for debate. Statutory History of the United States: 2 Civil Rights 1265 (B. Schwartz ed. 1970). Under this understanding of the 1964 Act:

In representative cases the Attorney General would step in and enforce for the citizen the rights which the citizen himself cannot otherwise enforce, and which a State may deny him with all the machinery of its government, its money, its officials, its police, its district attorneys, and its Governors, but which the United States grants him, and which, therefore, the Attorney General should seek to secure for him.

Id. When victims of discrimination are unable to carry the heavy burden of litigating their claim, "[t]he Attoney General becomes the active representative of the individual in securing the individual's Federal rights." Id. at 1266.

Title VI, likewise, can also be understood as authorizing the Attorney General to act on behalf of the victims of segregation. In Cannon v. University of Chicago, the Supreme Court suggested that one purpose of Title VI was "to provide individual citizens effective protection against" discriminatory practices. 441 U.S. 677, 704 (1979) (interpreting Title IX by reference to Title VI). In support of this claim, the Court quoted the comments of Representative Lindsay in the debate over Title VI:

This bill is designed for the protection of individuals. When an individual is wronged he can invoke the protection to himself, but if he is unable to do so because of economic distress or because of fear then the Federal Government is authorized to invoke protection for that individual ....

Id. at 704 n.36 (quoting 110 Cong. REC. 1540).

Congress has in another instance authorized an executive official to act as the legal representative of a discrete group. Under the Labor-Management Reporting and Disclosure Act (LMRDA), the Secretary of Labor is, in effect, appointed as the lawyer for labor union members for the purpose of enforcing rights granted under the statute, and is also charged with protecting the public interest in fair union elections. See Trbovich v. United Mine Workers of America, 404 U.S. 528, 538-39 (1972). In Trbovich the Court held that even where the Secretary of Labor was adequately fulfilling her duty to protect the public interest, a union member could still participate in the enforcement of the LMRDA by intervening under FED. R. CIV. P. 24(a)(2) if he had "a valid complaint about the performance of 'his lawyer'" (i.e., the Secretary). Id. at 539. 
for the wrongs inflicted upon them by state and local school authorities. This notion of a national interest in enforcing the prohibition of de jure school segregation, however, creates a false sense of unity-a false sense that an unambiguous body of doctrine exists, a false sense that the Department of Justice can act as a neutral enforcer of the law.

This fallacy is a product of the belief that a precise remedy flows with Newtonian certainty from a finding of violation. Yet, no such determinacy exists at the remedial stage of a school desegregation action. ${ }^{73}$ The remedy must be effective in dismantling the prior dual school system "root and branch;"'7t it must proceed without delay; ${ }^{75}$ and it must not place the burden of desegregation entirely on minority students. ${ }^{76}$ Within such broad remedial constraints, "[t]he precise remedy does not follow logically from the determination of liability, but rather reflects a careful reconciliation of the interests of the many affected members of the community and a choice among a wide range of possibilities." 77

To a degree, remedial indeterminacy may be a product of the effectiveness standard: "There is no universal answer to complex problems of desegregation; there is obviously no one plan that will do the job in every case." 78 For example, primarily because of differences in demographics, the plan that proved effective in Swann v. Charlotte-Mecklenburg Board of Education ${ }^{79}$ would have been of relatively little use in Milliken $v$. Bradley. ${ }^{80}$ Only through flexibility, the argument continues, can truly ef-

73. See Bickel, The Decade of School Desegregation: Progress and Prospects, 64 CoLum. L. REv. 193, 221 (1964). In Brown v. Board of Education, the Supreme Court wrote:

In fashioning and effectuating the decrees, the courts will be guided by equitable principles.

Traditionally, equity has been characterized by a practical flexibility in shaping its remedies and by a facility for adjusting and reconciling public and private needs. These cases call for the exercise of these traditional attributes of equity power.

349 U.S. 294, 300 (1955) (Brown II) (footnotes omitted).

74. Green v. County School Bd., 391 U.S. 430, 438 (1968).

75. See Griffin v. County School Bd., 377 U.S. 218, 234 (1964) ("The time for mere 'deliberate speed' has run out .....").

76. See NAACP v. Lansing Bd. of Educ., 559 F.2d 1042, 1052 (6th Cir.), cert. denied, 434 U.S. 997 (1977); United States v. Hendry County School Dist., 504 F.2d 550, 554 (5th Cir. 1974); Arvizu v. Waco Indep. School Dist., 495 F.2d 499, 504 (5th Cir. 1974); Lee v. Macon County Bd. of Educ., 448 F.2d 746, 753-54 \& n.12 (5th Cir. 1971); United States v. School Dist., 499 F. Supp. 367, 371 (E.D. Mich. 1980).

77. United States v. Board of Educ., 605 F.2d 573, 576 (2d Cir. 1979).

78. Green v. County School Bd., 391 U.S. 430, 439 (1968). "The matter must be assessed in light of the circumstances present and the options available in each instance." Id.

79. 402 U.S. 1 (1971).

80. 418 U.S. 717 (1974) (Milliken I). The busing remedy that proved effective in Swann, see Days, supra note 11 , at 322 n.62, could not desegregate the schools in Milliken because the student body there was predominantly black. The district court found that a redistributive remedy "would change a school system which is now Black and White to one that would be perceived as Black, thereby increasing the flight of Whites from the city and the system, thereby increasing the Black student population." Bradley v. Milliken, 484 F.2d 215, 244 (6th Cir. 1973) (quoting district court findings of fact). The district court further found that, unlike the situation in Swann, an effective integration remedy would have to involve Detroit's suburban school districts in an interdistrict reas- 
fective remedies be designed. Yet, the roots of remedial indeterminacy appear to run deeper than a need for flexibility. The Supreme Court's discussion of the goals of desegregation law has been consistently ambiguous: ${ }^{81}$ The objective of desegregation remedies is to remove the vestiges of past discrimination, to erase the legacy of de jure school segregation. ${ }^{82}$ To the extent that the Court has not articulated the precise goals of desegregation law, it cannot define what constitutes an effective remedy.

No matter what the source of this indeterminacy, current law does not define precise remedies and the debate over what are the proper remedies is fierce. ${ }^{83}$ Given the Court's imprecision in defining the law of school desegregation remedies, there is certainly no guarantee that the vision of school desegregation remedies adopted by the Department of Justice will comport with that of the victims of segregation.

\section{Representing the Victims of Segregation}

Finally, in the Justice Department's role as a representative of the victims of school segregation, the Department's representation is not an adequate proxy for direct participation by the victims themselves. A fundamental axiom of legal representation is that there must be a meaningful communication of interests and concerns between client and lawyer. ${ }^{84}$

signment plan with the city schools. Id. (quoting district court conclusions of law). The Supreme Court, in Milliken I, 418 U.S. 717 (1974), however, overturned the interdistrict relief ordered by the district court. The district court then responded with the flexibility characteristic of equity and ordered a compensatory education remedy. Bradley v. Milliken, 402 F. Supp. 1096, 1118-19 (E.D. Mich. 1975). The Supreme Court, in Milliken II, 433 U.S. 267 (1977), held that the order of remedial educational programs was within the court's discretion.

81. See Kirp, supra note 48, at 926-33 ("The persistent ambiguity of these decisions is attributable partly to the necessary imprecision of language, but more significantly to a willed lack of clarity in the opinions themselves."); Shane, School Desegregation Remedies and the Fair Governance of Schools, 132 U. PA. L. REv. 1041, 1044-77 (1984) (Court has failed to articulate clearly harms that remedies should redress); Yudof, Nondiscrimination and Beyond: The Search For Principle in Supreme Court Desegregation Decisions, in School Desegregation: Past, Present, and Future 97-115 (W. Stephan \& J. Feagin eds. 1980) (Burger and Warren Courts have failed to choose between remedial, political corruption, and group protection theories of school desegregation remedies).

82. See Swann v. Charlotte-Mecklenburg Bd. of Educ., 402 U.S. 1 (1971); Green v. County School Bd., 391 U.S. 430 (1968).

83. Compare, e.g., Bell, Serving Two Masters: Integration Ideals and Client Interests in School Desegregation Litigation, 85 YALE L.J. 470 (1976) (civil rights organizations have "convinced themselves that Brown stands for desegregation and not education," and thus have failed to seek educational improvement remedies, thereby failing to adequately represent substantial number of clients) with Jones, Correspondence, 86 YALE L.J. 378 (1976) (law requires desegregation, although educational components may be included in desegregation order).

84. One can hardly act as another's agent without knowing the principal's interests. This notion, as applied to lawyer-client relations, is expressed in MODEL Rules of Professional Conduct Rule 1.2(a) (1983), which specifies: "A lawyer shall abide by a client's decisions concerning the objectives of representation . . . and shall consult with the client as to the means by which they are to be pursued. A lawyer shall abide by a client's decision whether to accept an offer of settlement . . . ." See also Model Code of Professional Responsibility EC 7-7 (1980) ("it is for the client to decide whether he will accept a settlement offer"). 
Even strong advocates of paternalism do not suggest that individuals should be denied an opportunity to voice these interests. ${ }^{85}$ Certainly, failing to provide such an opportunity to be heard is an affront to the dignity of the client. ${ }^{86}$ Yet, the closed consent decree process denies students and their parents the opportunity to present their concerns. As a result, the Department of Justice does not act as an adequate representative under current practice. In fact, in recent years, the self-proclaimed posture of the Civil Rights Division in the settlement of school desegregation disputes has been adversarial with respect to groups of parents with views opposed to those of the Administration and their legal representatives. ${ }^{87}$ The Division's goal is to adopt a plan that comports with the Administration's "blueprint for desegregation." Attorney General acts more in accord with the role of representative of the Executive than as a representative of the victims of segregation.

Even if the Department of Justice did not face conflicting roles and could simply devote itself to representing the victims, representation of all aggrieved students and their parents would often be impossible. Consent decrees stress the remedial stage of a legal dispute ${ }^{89}$ Remedial judgments in school desegregation suits, however, are polycentric, with numerous valid interests tangled in a maze of opposition. ${ }^{90}$ For example, one group

85. Professor Duncan Kennedy defends paternalism against the charges that "the beneficiary's 'true' interests are unknowable" and that decisionmakers' "value judgments' are 'subjective,' and therefore uncertain, or "political" " by arguing that decisionmakers must come to know the beneficiaries. Kennedy, Distributive and Paternalist Motives in Contract and Tort Law, With Special Reference to Compulsory Terms and Unequal Bargaining Power, 41 Mo. L. Rev. 563, 636, 649 (1982). According to Professor Kennedy, then, true paternalism requires that beneficiaries voice their concerns to the decisionmaker.

86. See supra note 32 and accompanying text.

87. For example, in confirmation hearings on Assistant Attorney General William Bradford Reynolds' ultimately rejected nomination to serve as Associate Attorney General, the Lawyers' Committee for Civil Rights Under Law alleged that Reynolds instructed Department of Justice staff attorneys, with reference to some parents of Charleston, South Carolina minority school children and their representatives, to make "those bastards . . . jump through every hoop" before being afforded a voice in the negotiation of a pending consent decree. The Assistant Attorney General denied making this remark, but added: "In any event, most litigators approach litigation with an adversarial attitude. Thus, even were it accurate, such a passing remark about a potential party asserting an adverse interest in litigation simply does not support the sinister connotation suggested by the Lawyers' Committee." Hearings on the Confirmation of William Bradford Reynolds Before the Senate Comm. on the Judiciary, 99th Cong., 1st Sess. (1985) (testimony of William Bradford Reynolds, Assistant Attorney General for Givil Rights). Hence, at best, the Department of Justice views its role as adversarial with regard to those victims of school segregation who disagree with Department of Justice policy and their representatives.

88. See supra notes $17 \& 18$ and accompanying text.

89. See supra note 47 .

90.

We may visualize this kind of situation by thinking of a spider web. A pull on one strand will distribute tensions after a complicated pattern throughout the web as a whole. Doubling the original pull will, in all likelihood, not simply double each of the resulting tensions but will rather create a different complicated pattern of tensions. This would certainly occur, for example, if the doubled pull caused one or more of the weaker strands to snap. This is a "polycen- 
of parents may be deeply committed to integration while another group is equally committed to quality education as a remedy for past de jure segregation. Yet, in the course of negotiations, the representative of the parents might be forced to choose between the two. As Judge Weinstein has noted, groups with an apparent "unity of interest" in the desegregation of public schools often turn out to be in conflict.91

The negotiation of a school desegregation consent decree, as a result, requires the weighing of potentially conflicting interests. The Department of Justice cannot reasonably be expected to represent all the various interests at stake when it negotiates a consent decree and goes to court to ask that the settlement be approved. To the contrary, no one advocate can effectively represent the various interests at stake. In privately initiated and maintained class actions, this problem is addressed by Federal Rule of Givil Procedure 23(e), which allows disgruntled class members to challenge any settlement as unfair or inadequate. ${ }^{82}$ No such safeguard is currently available to provide a voice to unrepresented victims of school segregation when the suit is brought by the Department of Justice.

\section{InCreasing Participation Through Fairness Hearings}

Given these problems, why should we ever allow the Department of Justice to bring, and even more significantly, to compromise, school deseg-

tic" situation because it is "many centered"-each crossing of strands is a distinct center for distributing tensions.

Fuller, supra note 26, at 395.

91. See Weinstein, Litigation Seeking Changes in Public Behavior and Institutions-Some Views on Participation, 13 U.C.D. L. REv. 231, 233 (1980). See also Gewirtz, Remedies and Resistance, 92 YALE L.J. 585, 594-95 (1983) (footnote omitted) ("TT]here may be irreconcilable conflicts among the victims. . . . [T] ]hey may have conflicting views about what kind of benefits constitute an effective and appropriate remedy for the violation. These possible clashes of interest multiply in classes that have an evolving membership . . . ."); Rhode, Class Conflicts in Class Actions, 34 STAN. L. REv. 1183,1189 (1982) (footnote omitted) ("School desegregation cases provide the most well-documented instances of conflict. Both commentators and litigators have described . . . the balkanization within minority communities over fundamental questions of educational policy. Dispute has centered on the relative importance of integration, financial resources, minority control, and ethnic identification in enriching school environments."). For a discussion of conflicting interests between civil rights advocates and some of their clients, see Bell, supra note 83 .

When recognizing conflicting interests in school desegregation cases, it is important to avoid false dichotomies. For example, some have charged that busing is incompatible with quality education. See, e.g., S. 1647, 97th Cong., 1st Sess. § 2(b)(4) (1981) (bill proposing denying federal district courts jurisdiction to order busing or assignment remedies). This, however, is not the case:

Looking at the most common types of evidence used to judge educational quality, it seems safe to conclude that desegregation enhances rather than diminishes the academic achievement of minorities, especially when children are desegregated at an early grade. Moreover, desegregation does not impair, and may even facilitate, the achievement of whites.

Hearings Before the Subcomm. on Separation of Powers of the Senate Comm. on the Judiciary on $S$. 528., S. 1005, S. 1147., S. 1647., S. 1743 and S. 1760: Court-Ordered School Busing, 97th Cong, 1st Sess 117, 129 (1981) (testimony of Dean Willis D. Hawley). See also G. OrFIELD, MUST WE Bus? 119-26 (1978); Hawley, supra note 14, at 303.

92. See infra notes $99-107$ and accompanying text. 
regation suits? ${ }^{93}$ There are a number of arguments in favor of allowing Department of Justice suits and the settlement of those suits. The common thread running through each of these arguments is one of efficacy.

In providing for Department of Justice standing to bring school desegregation suits under the Civil Rights Act, Congress pointed to the paramount reason to allow Department of Justice suits: A system of private litigation is an insufficient protection against constitutional violations by relatively powerful state institutions such as school boards, particularly where the unconstitutional conduct has become an entrenched social pattern. ${ }^{94}$ In these cases, it may be necessary to employ the resources of the United States government in order to achieve meaningful relief.

The reasons for allowing the government to settle these suits likewise go to efficacy. First, consent decrees minimize the cost to the Department of Justice of litigating the case, thereby freeing resources to pursue other cases. ${ }^{95}$ Second, a lengthy trial can have an enormous cost to the children whose rights are being asserted; ${ }^{96}$ the longer the trial, the longer they have to wait to attend a unitary school system. Finally, consent decrees improve the spirit of community cooperation, and resistance is likely to be minimized if the remedial order is less authoritarian and more consensual. ${ }^{27} \mathrm{~A}$ consent decree may therefore achieve a more effective remedy than is possible in a fully litigated suit. ${ }^{98}$

Hence, while Department of Justice suits and consent decrees are im-

93. Commentators have attacked the prudence of both Department of Justice standing to bring school desegregation suits, see, e.g., Bickel, supra note 73, at 218-23, and settlement of cases calling for continuing judicial supervision, such as school desegregation cases, see, e.g., Fiss, supra note 47, at 1083.

94. See, e.g., Statutory History of the United States: 2 Civil Rights 1279-80 (B. Schwartz ed. 1970) (statement of Senator Paul Douglas).

95. See Armstrong v. Board of School Directors, 616 F.2d 305, 313 (7th Cir. 1980) (settlement of school desegregation disputes minimizes cost of litigation); United States v. Board of Educ., 88 F.R.D. 679, 681 (N.D. Ill. 1981) (same).

96. See United States v. Board of Educ., 88 F.R.D. 679, 681 (N.D. Ill. 1981) (settlement of school desegregation disputes provides students with remedy more expediently than litigation).

97. "Indeed, it appears that school desegregation is one of the areas in which voluntary resolution is preferable to full litigation because the spirit of cooperation inherent in good faith settlement is essential to the true long-range success of any desegregation remedy." Armstrong v. Board of School Directors, 616 F.2d 305, 318 (7th Cir. 1980). See also Williams v. Vukovich, 720 F.2d 909, 923 (6th Cir. 1983) (employment discrimination); Anderson, The Approval and Interpretation of Consent Decrees in Civil Rights Class Action Litigation, 1983 U. ILL. L. REv. 579, 580; Note, Voluntarily Unlocking the Schoolhouse Door: The Use of Class Action Consent Decrees in School Desegregation, 59 WASH. U.L.Q. 1305, 1309 (1982).

98. A fourth benefit of consent decrees does not go directly to the efficacy of remedying school segregation, yet should be considered nonetheless. Achieving justice without a long trial helps reduce the tremendous load now carried by the federal courts. See Armstrong v. Board of School Directors, 616 F.2d 305, 313 (7th Cir. 1980) (settlement "reduces the strain such litigation imposes upon already scarce judicial resources"); United States v. Board of Educ., 88 F.R.D. 679, 681 (N.D. Ill. 1981) (same). Reducing this burden is likely to promote justice on a more general level by allowing for the more prompt administration of justice and by allowing judges to devote closer attention to each case. 
perfect, at times their limitations may be outweighed by the drawbacks of privately litigated remedies. The imperfections of Department of Justice consent decrees can be minimized by creating a procedure that allows for extensive participation without undermining the potential for reaching a negotiated compromise. Such a procedure is embodied in Federal Rule of Civil Procedure 23(e).

All class litigation brought by private plaintiffs is governed by Rule 23(e), which requires judicial approval before a class suit is compromised. ${ }^{99}$ By extending this rule to cases brought by the Justice Department, even though they are not technically class actions, a much-needed symmetry would be achieved with private class suits. The strong presumption of adequate representation would be eliminated. Instead, the Attorney General would carry the same burden currently borne by private class representatives in school desegregation litigation.

Under Rule 23(e), the proponent of settlement carries the burden of showing that the settlement is fair, reasonable and adequate. ${ }^{100}$ Although the rule does not specify particular procedures for making this determination, at a minimum a two-step process is generally applied. ${ }^{101}$ First, the court makes a preliminary determination of whether the settlement is within the range of acceptable plans. ${ }^{102}$ Second, a fairness hearing is held to determine if the settlement is fair, reasonable and adequate. ${ }^{103}$ The criteria to be used in deciding whether the proponents of the settlement have effectively carried the burden of proof is in the trial judge's discretion-"[o]verall fairness is the touchstone for evaluating the conduct and resolution of class actions . . ."104 Several indicia, however, are frequently applied. These criteria include such factors as the strength of the plaintiffs' case on the merits balanced against the amount of settlement

99. "Dismissal or Compromise. A class action shall not be dismissed or compromised without the approval of the court, and notice of the proposed dismissal or compromise shall be given to all members of the class in such manner as the court directs." FED. R. Crv. P. 23(e).

100. See Mendoza v. United States, 623 F.2d 1338, 1348 (9th Cir. 1980), cert. denied, 450 U.S. 912 (1981); Armstong v. Board of School Directors, 616 F.2d 305, 313 (7th Cir. 1980); Manual. For Complex Litigation $\S 1.46$ (1982) (supplement to G. Wright \& A. Milleer, Federal Practice ANd Procedure (1969-85)).

101. See Armstrong, 616 F.2d at 314; Manual For Complex Litigation, supra note 100, at $\$ 1.46$.

102. Armstrong, 616 F.2d at 314; Manual For Complex Litigation, supra note 100 , at $\S$ 1.46; Developments in the Law-Class Actions, 89 HARv. L. Rev. 1318, 1566 (1976); Note, supra note 97, at 1321 .

103. See Armstrong, 616 F.2d at 314; MANuAl For Complex LrTigation, supra note 100, at $\$$ 1.46. Although a hearing is not explicitly called for by Rule 23(e), fairness hearings are "almost universally held" in school desegregation cases. Not holding a hearing "may well be an abuse of discretion." Mendoza v. United States, 623 F.2d 1338, 1348 n.8 (9th Cir. 1980), cert. denied, 450 U.S. 912 (1981). If there is any doubt as to the requirement of a fairness hearing, Congress could expressly provide for fairness hearings in cases involving Department of Justice settlement of school desegregation litigation. Cf. supra note 22; infra notes 112-20 and accompanying text.

104. Mendoza, 623 F.2d at 1344. 
offered; the defendant's ability to perform; the presence of collusion in reaching the settlement; the reaction of class members; the opinion of competent counsel; and the stage of the proceeding and amount of discovery completed. ${ }^{105}$ The judge must clearly set forth reasons for approving and disapproving a class settlement, ${ }^{108}$ and the court's decision is subject to appeal. ${ }^{107}$

Under the proposed approach, individuals and their representative groups currently excluded from the settlement negotiations could be notified by newspaper of a proposed settlement. ${ }^{108}$ They would subsequently be afforded an opportunity to appear informally before the court either to defend or criticize the decree. The adequacy of the decree would then be evaluated with regard to criteria like those that currently apply to class settlements. If the court finds that the decree is not fair, adequate and reasonable, the settlement would be disapproved and the Department of Justice would have to return to the negotiating table. ${ }^{108}$

Such a procedure would make available a peculiar, yet efficacious, form of participation to interested individuals. They would not actually partici-

105. See Armstrong, 616 F.2d at 314 (citing ManUal For Complex Lrtigation, supra note 100, at $\$ 1.46$ (1977); 3B J. Moore \& J. Kennedy, Moore's Federal Practice II 23.80[4] (2d ed. 1978)); Note, supra note 97, at 1326 (same).

106. See Armstrong, 616 F.2d at 315 ("[T]he district court must clearly set forth in the record its reasons for approving the settlement .... This is particularly important in civil rights class actions.") (citations omitted); Bryan v. Pittsburgh Plate Glass Co., 494 F.2d 799, 804 (3d Cir.), cert. denied, 419 U.S. 900 (1974) ("It is essential . . . that the district court set forth the reasoning supporting its conclusion in sufficient detail to make meaningful review possible . . . "). See also C. Wright, A. Miller \& M. Kane, Federal Practice and Procedure § 1792 (Supp. 1985).

107. Armstrong, 616 F.2d at 313; 3B J. MoORe \& J. Kennedy, MoOre's Federal Practice I 23.80[5] (2d ed. 1985). The appellate courts apply an abuse of discretion standard. See Armstrong, 616 F.2d at 313 .

108. Publication of notice in local newspapers can satisfy the due process requirement of Mullane v. Central Hanover Bank \& Trust Co.; notice must be "reasonably calculated, under all the circumstances, to apprise interested parties of the pendency of the action and afford them an opportunity to present their objections." 339 U.S. 306, 314 (1950). In Mendoza v. United States, a school desegregation case, the Ninth Circuit held that notice published thirteen times over the course of one week in two major local newspapers, in English and in Spanish, copies of which were distributed in the minority community (e.g., local merchants, churches and community centers) was reasonably calculated to apprise members of the class of the pending settlement. 623 F.2d 1338, 1351 \& n.18 (9th Cir. 1980), cert. denied, 450 U.S. 912 (1981). Because interested students and their parents are not formally, but only practically, bound by the settlement, see supra notes 52-54 and accompanying text, under the proposal advocated by this Note, such notice is not constitutionally required by Mullane; effective notice is, however, essential to promoting participation.

109. This burden currently applies in cases brought by private plaintiff class representatives and evidently is not excessive since private consent decrees are frequently approved. Recently, for example, private class consent decrees have been approved in school desegregation cases in St. Louis, Missouri, see Liddell v. Missouri, 731 F.2d 1294 (8th Cir.), cert. denied, 105 S. Ct. 82 (1984), and Cincinnati, Ohio, see Bronson v. Board of Educ., 604 F. Supp. 68 (S.D. Ohio 1984). The Rule 23(c) approval requirement, however, is not without teeth. As Professor Miller has noted, "the scrutiny given to proposed settlements under Rule 23(e) has intensified, and several judges have rejected proposals as unfair or inadequately justified by the papers." Miller, Of Frankenstein Monsters and Shining Knights: Myth, Reality, and the "Class Action Problem", 92 Harv. L. Rev. 664, 681 (1979) (footnote omitted). See, e.g., Williams v. Vukovich, 720 F.2d 909 (6th Cir. 1983). 
pate in the negotiation of the decree. However, their presence would inevitably be felt during the negotiations. The negotiators would have to be sensitive to interests outside of the bargaining room out of fear of disapproval of the plan. In fact, a prudent negotiator would seek input from interested parties. This reflective participation would be overseen by the judiciary, thus protecting against the sacrifice of minority interests in favor of the political majority. ${ }^{110}$ Furthermore, affected individuals would have their day in court and hence would not be denied the dignity of participation. In short, the instrumental and intrinsic goals of participation can be served while preserving the process of negotiation and the benefits of avoiding full litigation of the case. Although some additional costs would be created, at least one federal judge has asserted that the costs associated with maintaining fairness hearings is not prohibitive. ${ }^{111}$

Moreover, Congressional action to enhance participation by the public in judicial proceedings initiated by the federal government is not unprecedented. As early as the 1940's, Justice Department consent decrees in antitrust cases were criticized as being overly politicized. Courts would "rubber stamp"112 whatever agreement the Antitrust Division reached with the defendant corporations. ${ }^{113}$ The consent decrees were generally negotiated in private without public input. ${ }^{114}$ Congress reacted to concerns over the procedural inequity of this process ${ }^{115}$ by passing the Tunney Act. ${ }^{116}$ The Tunney Act requires the Justice Department to publish notice of its intent to settle a case along with the proposed settlement and an impact statement and provides for public comment and Justice Depart-

110. For a discussion of structural steps taken by the Framers of the Constitution to insulate the judiciary from majoritarian political forces, see THE FEDERALIST No. 78 (A. Hamilton) (life tenure and fixed compensation provisions help ensure independence of federal judges); J. STORY, A FAMILiar EXPOSITION of THE Constirution of the UnITEd States $\$ \$ 303 \& 306$ (1872) (same). $C f$. J. Ely, Democracy and Distrust (1980) (judicial review properly protects minorities from abuses of majoritarian political process).

111. See Weinstein, supra note 91 , at 246 (opening structural proceedings is practicable because the number of persons who want to appear is small in proportion to number affected and "most people are quite sensible" and thus willing to limit length of their presentations).

112. See H.R. REP. No. 1463, 93d Cong., 2d Sess. 8, reprinted in 1974 U.S. Code Cong. \& AD. NEws 6535,6538 .

113. See Note, The ITT Dividend: Reform of Department of Justice Consent Decree Procedures, 73 Colum. L. Rev. 594, 600 (1973).

114. See id. at $600-01$.

115. In 1972, the need for reform was demonstrated by three antitrust suits brought against ITT for violations of section 7 of the Clayton Act. The reasons for settlement of these suits became public. They included the usual balancing of the likelihood of success against the terms of the settlement. However, the Antitrust Division also considered issues that were less clearly within its domain, such as the "'hardship' to ITT, its stockholders, and the economy" that would result if divestiture was required. In addition, allegations arose suggesting a connection between the Administration's decision to settle the case and an offer by ITT to help finance the 1972 Republican National Convention. See id. at 603-04.

116. Antitrust Procedures and Penalties Act of 1974, Pub. L. No. 93-528, §2, 88 Stat. 1706 (codified at 15 U.S.C. $\S 16(e)(1982)$ ). 
ment responses. ${ }^{117}$ In considering whether to approve the consent decree, the judge must determine whether it is "in the public interest." 118 Determination of the public interest is left to the judge and is to be aided by public input. ${ }^{119}$ The executive's view of the public interest is thus not definitive. ${ }^{120}$

Recent studies indicate that under the Tunney Act increased procedural protection is afforded without decreasing the number of cases brought. ${ }^{121}$ Although Rule 23(e) fairness hearings are not identical to the procedure set forth by the Tunney Act, there is no reason to believe that the burden on the Justice Department would be greater. Thus, it is unlikely that fairness hearings would interfere with the Civil Rights Division's ability effectively to enforce the law.

\section{CONCLUSION}

To fail to provide the victims of school segregation with an opportunity to participate in defining the remedies for the wrongs they have suffered is to fail to provide a satisfactory remedial process. Devising a remedy without this participation unnecessarily ignores invaluable information and excludes the victims once again from a position of dignity and influence. Furthermore, the remedies take on a character of privilege rather than right. Absent participation, the party negotiating the decree, here the Department of Justice, can settle on behalf of the victims for less than is legally obtainable. The negotiator can settle for three magnet schools instead of ten; she can settle for a remedy that automatically terminates after three years, rather than continuing until it has accomplished its goal. Providing a right to participate in fashioning a fair and adequate remedy

117. See H.R. REP. No. 528, 93d Cong., 2d Sess. 7, reprinted in 1974 U.S. Code Cong. \& Ad. NEws 6535, 6538.

118. Id. at 8, reprinted in 1974 U.S. CoDE CoNG. \& AD. News at 6538.

119. See S. ReP. No. 298, 93d Cong., 1st Sess. 4 (1973).

120. Congress has also provided for public participation in the criminal setting. Under the federal Victim and Witness Protection Act of 1982, Pub. L. No. 97-291, 96 Stat. 1248 (codified at 18 U.S.C. $\S \S 1501$ note, 1503, 1505, 1510, 1512 note, 1512-1515, 3146 note, 3579, 3580 (1982)), a federal prosecuting attorney is required to consult with the victim of a crime concerning plea bargaining-the criminal analogue of a consent decree, 18 U.S.C. $\$ 1512$ note (1982); ATTORNEY GENERAL's GuIDELINES FOR VICTIM AND WITNESS ASSISTANCE (July 9, 1983), reprinted in 33 CRIM. L. REP. (BNA) 3329 (Aug. 3, 1983). The consultation provision may be interpreted to require judicial involvement or approval. See Goldstein, The Victim and Prosecutorial Discretion: The Federal Victim and Witness Protection Act of 1982, 47 LAw \& Contemp. Probs. 225, 232-33 (1984).

121. "[I]t is interesting to note that statistics on the number of cases brought and the number settled by consent decree lend no support to the argument that the [Tunney Act] is forcing the Antitrust Division to try a larger percentage of cases or is inhibiting it from bringing as many cases." Branfman, Antitrust Consent Decrees-A Review and Evaluation of the First Seven Years Under the Antitrust Procedure and Penalty Act, 27 ANTrTrust Bull. 303, 352-53 (1982) (footnotes omitted). See also Note, The Scope of Judicial Review of Consent Decrees Under the Antitrust Procedures and Penalties Act of 1974, 82 MICH. L. Rev. 153, 171 (1983) (intensive judicial review of antitrust settlements has minimal effect on incentive to settle). 


\section{School Desegregation Consent Decrees}

under Rule 23(e) would help insure that the victims of segregation have the access necessary to acquire the remedy that is their legal right and would empower them to see to it that they are not once again shortchanged. 